\title{
THE JURY REDEFINED: A REVIEW OF BURGER COURT DECISIONS
}

\author{
Marjorie S. Schultz*
}

In the decade since Warren Burger replaced Earl Warren as Chief Justice, the Supreme Court has decided over thirty cases dealing with the right to jury trial, redefining the breadth of the right and the composition of a constitutionally-required jury. Section I will examine decisions affecting the right to trial by jury and illustrate the Burger Court's decision to constrict the right by refusing to extend jury trials to juveniles or to state civil proceedings, by widening the category of "petty" offenses to which the right does not extend, by recognizing a "statutory proceedings" exception to the right in federal civil suits, and by refusing to make certain landmark decisions apply retroactively.

Section II deals with compositional issues which have been addressed by the Court in the last ten years such as the size, representativeness, and bias of juries, and the requirement of unanimous verdicts.

I

The Right to a Trial by Jury

A. Defusing Duncan

The Warren Court's 1968 decision in Duncan $v$. Louisiana ${ }^{1}$ was a milestone in the history of the American jury. During the nearly three centuries preceding the case, each state legislature had been free to expand or constrict the right to jury trial in its state courts, limited only by applicable provisions of the state's constitution. The Supreme Court in Duncan held that the right to a jury trial in criminal cases found in the Sixth Amendment is "incorporated" into the Fourteenth Amendment definition of due process, and thus applies to the states. Writing for the Court, Justice White reviewed the history of the jury and concluded that, "in the American States, as in the federal judicial system, a general grant of jury trial for serious offenses is a fundamental right, essential for preventing miscarriages of justice and for assuring that fair trials are provided for all defendants." 2 He qualified the breadth of the right

* Attorney, Fulbright \& Jaworski, Houston, Texas

1. 391 U.S. 145 (1968).

2. 391 U.S. at 157-58. Incidentally, Justice White has become the foremost spokesman for the Court on jury issues, having written sixteen majority opinions on the subject since taking his seat on the Court in 1962. Included are: Atlas Roofing Co. v. Occupational Safety and Health Review Comm'n, 430 U.S. 442 (I977); Muniz v. Hoffman, 422 U.S. 454 (1975); Taylor v. Louisiana, 419 U.S. 522 (1975); Codispoti v. Pennsylvania, 418 U.S. 506 (1974); Taylor v. Hayes, 418 U.S. 488 (1974); Johnson v. Louisiana, 406 U.S. 356 (1972); Williams v. Florida, 399 U.S. 78 (1970); Bald- 
by stating that waivers are not unconstitutional, nor is "prosecuting petty crimes without extending a right to jury trial."3 These qualifications have been explored and refined by later Supreme Court decisions. ${ }^{4}$

The implications of Duncan were far-reaching. The decision seemed destined to bring about a uniform system of criminal justice for the state and federal courts. This move toward uniformity was not applauded by Justices Harlan and Stewart, who, in their dissenting opinion in Duncan, saw grave problems ahead. They saw the states being forced into lockstep conformity with the federal interpretations of due process-states which might otherwise serve as laboratories for developing novel solutions to problems within the criminal justice system but for Duncan. They also saw a potential threat to the jury as it existed in the federal scheme. Harlan and Stewart favored allowing the states to adopt their own interpretations of the right to jury trial expressed in each state's constitution, subject only to a standard of "basic fairness." 5 Within their dissent are the seeds of decisions which the Court would reach in the following decade concerning the extent to which unanimous verdicts, juries of twelve, and impartial jury panels are fundamental aspects of the right to trial by jury. ${ }^{6}$

The Burger Court refused to extend the right granted in Duncan to juveniles in In Re Burrus and McKeiver $v$. Pennsylvania, ${ }^{7}$ decided in 1971. There was no majority opinion, but Justice Blackmun, writing for Burger, Stewart and White, stated that a juvenile court proceeding is not a criminal prosecution within the Sixth Amendment, ${ }^{8}$ despite the fact that

juveniles over 16 are, in fact, held in the cells of a prison; that counsel and the prosecution engage in plea bargaining; ... that the press is generally admitted in the Philadelphia juvenile courtrooms; . . . that arrest and prior record may be reported by the press . . .; that, once adjudged delinquent, a juvenile may be confined until his majority in what amounts to a prison . . .; and that the stigma attached upon delinquency adjudication approximates that resulting from conviction in an adult criminal proceeding. ${ }^{9}$

The standard adopted by the court was the fundamental fairness standard gleaned from prior decisions regarding juveniles ${ }^{10}$ - the same standard

win v. New York, 399 U.S. 66 (1970); Parker v. North Carolina, 397 U.S. 790 (1970); McMann v. Richardson, 397 U.S. 759 (1970); Brady v. United States, 397 U.S. 742 (1970); Dyke v. Taylor Implement Mfg. Co., 391 U.S. 216 (1968); Bloom v. Illinois, 391 U.S. 194 (1968); Duncan v. Louisiana, 391 U.S. 145 (1968); Katchen v. Landy. 382 U.S. 323 (1966); and Swain v. Alabama, 380 U.S. $202(1965)$.

3. 391 U.S. at 158.

4. See text and notes at 13-15, infra.

5. 391 U.S. at 172 (Harlan, J., dissenting).

6. See id. at 181-83.

7. 403 U.S. 528 (1971).

8. Id. at 541 .

9. Id. at 542.

10. See In re Winship, 397 U.S. 358 (1970) and In re Gault, 387 U.S. 1 (1967). 
proposed by Harlan and Stewart in their Duncan dissent. ${ }^{11}$ Harlan, in fact, concurred in the McKeiver case on the same grounds that had led to his dissent in Duncan. ${ }^{12}$ Justice White, author of the Duncan opinion, was sufficiently convinced of the differences in juvenile and adult proceedings to join the plurality opinion, while Justice Brennan equated admission of members of the press and public to juvenile trials with the right to jury trial because a certain amount of protection against "judicial oppression" ${ }^{3}$ may result from exposing the proceedings to public scrutiny.

The Burger Court further restricted the right to jury trial in 1973 in Alexander $v$. Virginia ${ }^{14}$ a suit brought to incorporate the Seventh Amendment right to jury trial in civil cases into the Fourteenth Amendment. The case is especially significant because the issue was whether certain materials were obscene, and the Supreme Court had previously enunciated a "community standards" test ${ }^{15}$ which seemed to indicate that the obscenity question was one for a jury. The appellants had contended that a state statute providing for a judicial determination of an obscenity question was unconstitutional. ${ }^{16}$ The Virginia court's affirmance of the judgment that a jury trial is not mandated in such proceedings was summarily affirmed by the Supreme Court, making Alexander a definitive statement of the Court's refusal to incorporate the Seventh Amendment. At present, only the Second and Third Amendments and the Fifth Amendment right to grand jury indictment stand with the right to jury trial in civil cases as the Bill of Rights guarantees which do not bind the states.

\section{B. "Petty" Offenses}

Justice White's reference to the petty offenses exception to the right to a jury trial in Duncan ${ }^{17}$ relates to such Warren Court decisions as Cheff $v$. Schnackenberg, ${ }^{18}$ Shillitani $v$. United States, ${ }^{19}$ Bloom v. Illinois, ${ }^{20}$ and Dyke v. Taylor Implement $\mathrm{Mfg}$. Co. ${ }^{21}$ (decided the same day as Duncan), which had generally delineated the right to jury trial in criminal contempt cases by defining petty crimes in accordance with 18 U.S.C. $\$ 1(3)$-those for which the maximum sentence which can be imposed is no longer than six months (or for which the actual sentence imposed is six months or less or $\$ 500$ or both, as in a case like Bloom where the statute carried no maximum penalty ${ }^{22}$ ).

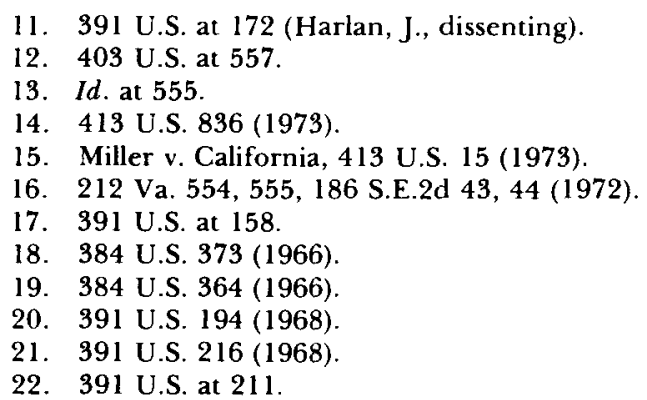


In 1969, the four members of the Burger Court who also served on the Warren Court were joined by Harlan in the majority opinion in Frank $v$. United States, ${ }^{23}$ another criminal contempt case, but this one involved federal rather than state law. The defendant was given a suspended sentence and placed on probation for three years. Marshall, writing for the majority, noted that while probation is "a significant infringement of personal freedom, . . . it is certainly less onerous a restraint than jail itself."24 Chief Justice Warren expressed fear in his dissent that judicial power to place such significant restraints on an individual's freedom without a jury conviction could chill the exercise of constitutional rights by defendants who were members of unpopular groups or movements, a common phenomena of the late $1960 \mathrm{s.}^{25}$ Because a violation of probation could cost the defendant an additional six months in prison, the Cheff six-month test was compromised by Frank.

The Cheff test, as modified by Frank, was followed by a plurality of the Court to reverse a conviction for "jostling" which New York had described as a petty offense and for which the maximum sentence of one year had been imposed in Baldwin $v$. New York, ${ }^{26}$ but signs of a softening of the test appeared four years later in Taylor $v$. Hayes ${ }^{27}$ and Codispoti $v$. Pennsylvania. ${ }^{28}$ The defendant in Taylor was sentenced in a post-trial adjudication on multiple charges of contempt to nine consecutive terms of six months or more. The sentences were later amended to six-month concurrent terms which were approved by the Court. ${ }^{29}$ Codispoti also involved multiple contempt charges, but the prison sentences handed down in a post-verdict adjudication aggregated to well over six months. In reversing the sentences, the plurality drew a distinction between contempt matters which have been dealt with as distinct and separate charges during the course of a trial and post-verdict adjudications for which the sentences might aggregate more than six months. The former were held triable without a jury for the sake of maintaining courtroom order and decorum..$^{30}$

In Muniz $v$. Hoffman, ${ }^{31}$ the Court indicated that the $\$ 500$ fine rule defining petty offenses for which jury trial need not be accorded defendants is relative, perhaps to the resources of the particular defendant. The defendant, a labor union with over 13,000 members, was fined $\$ 10,000$ for violating a National

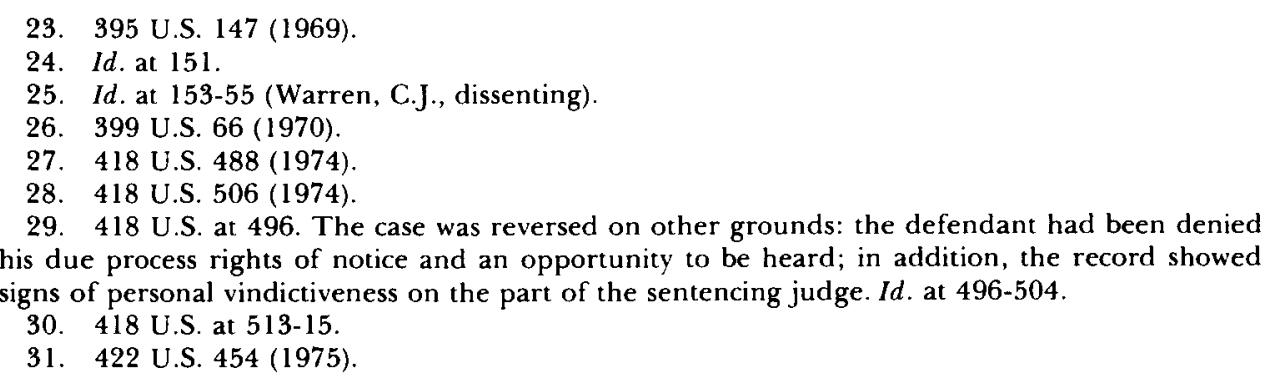


Labor Relations Board order against picketing. Again, Justice White wrote for the majority which decided that the imposition of even so large a fine did not transform the offense into one for which a jury trial is mandated. ${ }^{32}$ In doing so, the Court left open the question whether a jury trial is ever required in cases involving a corporate defendant where the only penalty imposed is a fine. ${ }^{33}$

\section{The "Statutory Proceedings" Exception}

Three Burger Court decisions explore the effect of the creation of federal rights by statute upon the Seventh Amendment right to a jury trial. Curtis $v$. Loether $^{\mathbf{3 4}}$ was a Title VIII suit for damages resulting from alleged unfair housing practices. The defendants sought a jury trial but their request was refused. The Supreme Court, in upholding the Court of Appeals reversal, stated that "when Congress provides for enforcement of statutory rights in an ordinary civil action in the district courts, where there is obviously no functional justification for denying the jury trial right, a jury trial must be available if the action involves rights and remedies of the sort typically enforced in an action at law." [emphasis added] ${ }^{35}$

This focus on the forum is especially pronounced in the 1977 case, Atlas Roofing Co. v. Occupational Safety and Health Review Commission. ${ }^{36}$ A proceeding under $\mathrm{OSHA}^{37}$ before an administrative law judge resulted in the imposition of fines, with the collection of those fines enforced in federal district court. The statute provides that the enforcing court may not retry questions of fact or propriety of the violation. ${ }^{38}$ Thus, the employer is effectively deprived of a jury trial on the merits. In a unanimous decision, the Court held that Congress may create new statutory "public rights" and may provide for administrative rather than judicial determinations without running afoul of the Seventh Amendment. ${ }^{39}$ The opinion distinguished cases involving enforcement of private rights, saying that fact-finding by an administrative agency in such cases will only serve to supplement the jury's function, not to replace it altogether. ${ }^{40}$

Finally, in Lorillard $v$. Pons, ${ }^{41}$ a statutory scheme which creates a private right of action for victims of age discrimination in employment ${ }^{42}$ was inter-

32. Id. at $477-78$.

33. Id. at 477 .

34. 415 U.S. 189 (1974)

35. Id. at 195.

36. 430 U.S. 442 (1977).

37. Occupational Safety and Health Act of 1970, 29 U.S.C. $\$ 651-78$ (1976).

38. 29 U.S.C. $\$ 660$ (a) (1976).

39. 430 U.S. at 455 .

40. Id. at $450 \mathrm{n} .7$.

41. 434 U.S. 575 (1978).

42. Age Discrimination in Employment Act of 1967, 29 U.S.C. $\S 621-34$ (1976), (1970, Supp. V). 
preted to provide a right to jury trial. Writing for a unanimous Court, Justice Marshall found the necessary congressional intent in the statutory language authorizing both "legal or equitable relief," 43 the word legal being a term of art which indicates the right to jury trial is attached to the cause of action.

It now appears that private legal rights created by federal statute and enforceable in judicial proceedings carry the right to jury trial, whereas statutorily-created public rights may be enforced without jury trials.

\section{Waiver of the Right}

In United States $v$. Jackson, ${ }^{44}$ the Warren Court declared a portion of the Federal Kidnapping $\mathrm{Act}^{45}$ to be unconstitutional as an impermissible burden on the exercise of the right to trial by jury. The Act provided for the death penalty only if a jury so recommended. By waiving his right to a jury trial, a defendant could assure no more than a life sentence. Thus, the assertion of the right to jury trial carried with it the risk of capital punishment. The Court struck the offending clause but upheld the portion of the Act making kidnapping a federal offense. ${ }^{46}$

Two years later, the Burger Court refused to apply the Jackson decision to overturn a conviction based on the same statute in Brady $v$. United States. ${ }^{47}$ In Brady, the defendant's co-conspirator had confessed and was prepared to testify for the state, thus giving the defendant added impetus to plead guilty and waive a jury trial. The Court held that where the offending statute was only a part of the reason for the guilty plea, the plea could still be held to be "voluntarily and knowingly made."48 "[E]ven if we assume that Brady would not have pleaded guilty except for the death penalty provision . . . , this assumption merely identifies the penalty provision as a 'but for' cause of his plea. That the statute caused the plea in this sense does not necessarily prove that the plea was coerced and invalid as an involuntary act." 49 Justice White compared the statute's effect to that of plea bargaining in which a guilty plea to a lesser offense is encouraged in order to avoid trial on the more serious

\footnotetext{
43. 29 U.S.C. $\$ 626(\mathrm{~b})$, quoted in 434 U.S. at 583.

44. 390 U.S. 570 (1968).

45. 18 U.S.C. $\$ 1201$ (a) (1976).

46. 390 U.S. at 591. The decision in Jackson brought a wave of cases before the Court on this issue of voluntary waiver of constitutional rights. In McCarthy v. United States, 394 U.S. 459 (1969), the majority read Federal Rule of Criminal Procedure 11 strictly in overturning the guilty plea of a defendant on a technicality. The defendant had not been addressed personally by the judge concerning his understanding of the charge to which he was pleading guilty, although he admitted that he had understood the charge and its consequences at the time of his plea. Chief Justice Warren cited the serious consequences of a guilty plea, among them, waiver of the right to jury trial, as the justification for strict compliance with the Rule. Id. at 466.

See also Boykin v. Alabama, 395 U.S. 238 (1969), in which a guilty plea was reversed because the record did not indicate whether the judge had ascertained the voluntariness of the plea.

47. 397 U.S. 742 (1970).

48. Id. at 745 .

49. Id. at 750 .
} 
charge. "We decline to hold . . . that a guilty plea is compelled and invalid . . whenever motivated by the defendant's desire to accept the certainty or probability of a lesser penalty rather than face a wider range of possibilities extending from acquittal to conviction and a higher penalty authorized by law for the crime charged." 50

Two other cases decided with Brady further weaken the impact of Jackson: McMann v. Richardson ${ }^{51}$ and Parker $v$. North Carolina ${ }^{52}$ involved pleas of guilty following coerced confessions. In upholding the guilty pleas in McMann, Justice White focused on the role of counsel's advice, saying,

[w] hether a plea of guilty is unintelligent and therefore vulnerable when motivated by a confession erroneously thought admissible in evidence depends as an initial matter, not on whether a court would retrospectively consider counsel's advice to be right or wrong, but on whether that advice was within the range of competence demanded of attorneys in criminal cases. ${ }^{53}$

The Brady, McMann and Parker decisions drew sharp criticism from Justice Brennan, joined by Marshall and Douglas. The dissenters, in interpreting the Brady opinion, felt the Court had held "that never, except perhaps in highly unrealistic hypothetical situations, will the constitutional defects identified in Jackson vitiate a guilty plea." ${ }^{44}$ Citing as one of the "grave consequences" accompanying a plea of guilty the "simultaneous surrender" of the right to a jury trial "with all of its attendant safeguards," 55 Brennan urged that the focus of these cases should have been on the governmental action which served to coerce the pleas (whether by physical threats, promises of leniency, or by unconstitutional statutory schemes) rather than on the role of the defendants' counsels. "[I]t hardly follows that the support provided by counsel is sufficient by itself to insulate the accused from the effect of any threat or promise by the government." 56

Justice White's assessment of the constitutionality of the threats and promises made during the plea bargaining process was recently affirmed in Bordenkircher $v$. Hayes. ${ }^{57}$ Here the prosecutor gave the defendant, who had been convicted of felonies twice previously, the choice between pleading guilty to a third charge or opting for a jury trial ${ }^{58}$ and having a recidivism charge, which carried a mandatory life sentence, added. Following Parker, Justice Stewart seems to have forgotten the concerns he so clearly expressed in

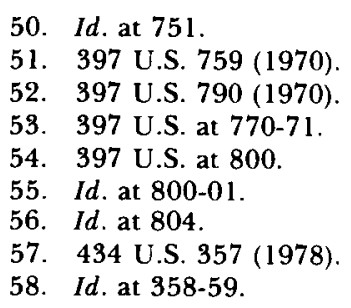


Jackson ${ }^{59}$ when he states in Bordenkircher that the "discouraging effect" which a threat of a more serious charge may have upon the "defendant's assertion of his trial rights" is merely part of the "simple reality" of a judicial system which allows plea bargaining. ${ }^{60}$

Thus, in the decade since Jackson, the case has been reduced to a narrow holding which will benefit only those convicted to die under the antiquated Federal Kidnapping Act. Justice Brennan's dissent in Parker v. North Carolina notes the irony of the situation by comparing the fates of those possibly innocent defendants who were so afraid of the threatened death sentence that they pleaded guilty or waived their right to a jury trial, and those who were adjudged guilty and deserving of the death sentence by a jury-only the latter are aided by the Jackson holding as modified by Brady and subsequent cases. ${ }^{61}$

II

\section{Compositional Issues}

With the Duncan decision, state and federal requirements for juries merged, resulting in some significant alterations in the area of jury composition. Four aspects of this area will be examined: size, unanimity, representativeness, and bias.

\section{A. Size}

The constitutionally-required jury is no longer necessarily made up of twelve persons. Justice White's opinion in Williams $v$. Florida ${ }^{62}$ termed the traditional number of twelve jurors to have been a "historical accident, unrelated to the great purposes which gave rise to the jury in the first place." ${ }^{33}$ He went on to say:

The purpose of the jury trial, . . is to prevent oppression by the Government ... The performance of this role is not a function of the particular number of the body that makes up the jury. To be sure, the number should probably be large enough to promote group deliberation, free from outside attempts at intimidation, and to provide a fair possibility for obtaining a representative cross-section of the community. But we find little reason to think that those goals are in any meaningful sense less likely to be achieved when the jury numbers six, than when it numbers [twelve]-particularly if the requirement of unanimity is retained. ${ }^{64}$

The fears expressed by Harlan and Stewart in their Duncan dissent are reiterated in their separate opinions in Williams, namely that the "incorporation" of the right to jury trial into the Fourteenth Amendment would result both in

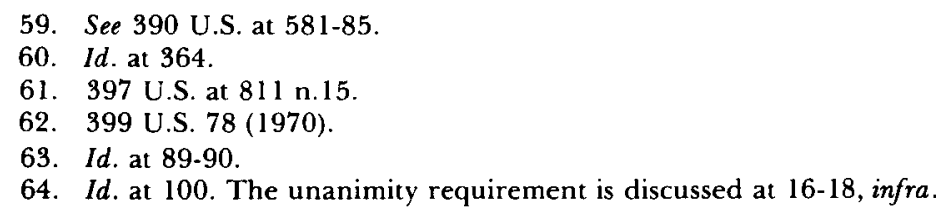


stifling the creativity of the states in adopting novel solutions to judicial problems and experimenting in the realm of jury composition while diluting the federal right to trial by jury in efforts to preserve some flexibility in the state systems. ${ }^{65}$ These fears reached fruition in Colgrove $v$. Battin $^{66}$ which extended the six-member jury concept to the federal courts for suits tried to a jury under the Seventh Amendment.

Finally, in Ballew v. Georgia, ${ }^{67}$ the line was drawn between five-member and six-member juries, the former being found unconstitutionally small, at least for criminal trials. Although all agreed that five jurors were too few, there was no agreement as to why, as the five separate opinions indicate. The Blackmun opinion relies heavily on statistics taken from experts' studies of group dynamics in the field of jury research and concludes that reliability and representativeness of juries is significantly reduced when the number of jurors is less than six. ${ }^{68}$ Powell, joined by Burger and Rehnquist, rejected the reliance on social science data and merely stated that "a line has to be drawn somewhere." ${ }^{9}$ So, for whatever reason, six are enough while five are not.

\section{B. Unanimity}

In DeStefano v. Woods, ${ }^{70}$ the Warren Court sidestepped the issue of the constitutionality of nonunanimous verdicts in state criminal trials by refusing to apply the Duncan case retroactively. The issue was open to question until 1972 when the Burger Court approved less than unanimous verdicts in Johnson $v$. Louisiana ${ }^{71}$ and Apodaca $v$. Oregon. ${ }^{72}$

In Johnson, the appellant conceded that the Duncan rule did not apply to his case since it, like DeStefano, arose before Duncan was decided. He therefore relied on due process and equal protection claims, saying that a conviction by a less than unanimous jury indicates jurors were not convinced of his guilt beyond a reasonable doubt. The Louisiana statute provided for conviction by a majority of nine in cases providing punishment at hard labor while requiring unanimous verdicts in capital cases. Apodaca involved criminal convictions by less than unanimous juries after the Duncan decision had been rendered. The Oregon statute allowed conviction by a majority of ten in noncapital cases.

At the heart of the argument is the question how much deliberation time is essential for reaching a fair verdict and in the end, whether it is desirable to render seriously dissenting jurors powerless to hang the jury. With a

65. See 399 U.S. at 117-38 (Harlan, J., dissenting), 399 U.S. at 143-45 (Stewart, J., dissenting).

66. 413 U.S. 149 (1973).

67. 435 U.S. 223 (1978).

68. See id. at $232-39$.

69. Id. at 246 .

70. 392 U.S. 631 (1968).

71. 406 U.S. 356 (1972).

72. 406 U.S. 404 (1972). 
unanimity requirement, jury deliberation proceeds as long as the trial judge is convinced there is a possibility that the jury can reach a verdict. But if a unanimous verdict is not required, can the jury take a vote immediately upon selecting a foreperson or does the right to jury trial include the right to jury deliberation as well?

Justice White, writing for the Court, placed his faith in the keen sense of responsibility felt by jurors when he stated:

We have no grounds for believing that majority jurors, aware of their responsibility and power over the liberty of the defendant, would simply refuse to listen to arguments presented to them in favor of acquittal, terminate discussion, and render a verdict. On the contrary it is far more likely that a juror presenting reasoned argument in favor of acquittal would either have his arguments answered or would carry enough other jurors with him to prevent conviction. A majority will cease discussion and outvote a minority only after reasoned discussion has ceased to have a persuasive effect or to serve any other purpose-when a minority, that is, continues to insist upon acquittal without having persuasive reasons in support of its position. ${ }^{73}$

Justice Douglas, with whom Brennan and Marshall joined dissenting, was not so charitable as to rely on the majority jurors' sense of justice to protect the right to jury deliberation. He noted that if a necessary majority is reached on the first ballot, there is no need for deliberation. As a matter of fact, the verdict in Apodaca was rendered in only forty-one minutes. ${ }^{74}$

In the cojoining of Williams $v$. Florida ${ }^{75}$ (jury of less than twelve) and Johnson and Apodaca, Douglas saw a "parade of horribles"-convictions by a three-to-two majority or even two-to-one, followed, perhaps, by the elimination of the presumption of innocence and proof beyond a reasonable doubt. ${ }^{76}$ Some of these fears were put to rest recently in Burch $v$. Louisiana, ${ }^{77}$ where the Court drew another line over which the states may not step when it held that five-to-one verdicts violate a defendant's rights under the Sixth and Fourteenth Amendments. Justice Rehnquist's majority opinion used the reasoning some had employed in Ballew ${ }^{78}$ (invalidating five-person juries), namely that the line must be drawn somewhere. Since Ballew held that a unanimous verdict by a jury of five is not valid, the invalidation of a five-toone verdict from a jury of six follows logically.

A question which remains unanswered is the extent to which compositional requirements for juries in state and federal trials must coincide. After Johnson and Apodaca, state courts are free to allow nonunanimous verdicts while federal courts are not. The Brennan dissent in Johnson points out that a majority

73. 406 U.S. at 361 (1972).

74. Id. at 389 (Douglas, J., dissenting).

75. 399 U.S. $78(1970)$.

76. 406 U.S. 393-94 (Douglas, J., dissenting).

77. 441 U.S. 130 (1979).

78. 435 U.S. 223 (1978). See text accompanying notes 64-66 supra. 
of the Court felt that federal juries must render unanimous verdicts while states may validate non-unanimous ones; a different majority agreed that the Sixth Amendment right applies to state and federal trials in an identical fashion. ${ }^{79}$ This inconsistency has yet to be resolved.

\section{Representativeness}

The extent to which a jury pool should represent a cross section of the community has been clarified in the past decade in decisions involving racial, sexual and philosophical representativeness.

\section{Race}

Systematic exclusion of members of one race from a jury pool was held unconstitutional in Swain $v$. Alabama ${ }^{80}$ in 1965, but the defendant had the burden of proving the exclusion had occurred. Then in 1967, the Court held that gross disparity between the percentage of blacks in a community and the percentage of blacks in a jury pool creates a prima facie case of unconstitutional systematic exclusion, and places the burden on the state to explain the discrepancy. ${ }^{81}$

In Carter v. Jury Commission of Greene County ${ }^{82}$ qualified black jurors who had never been called to serve sought an injunction to prevent further systematic exclusion of blacks from the jury pool. The discussion of the plaintiffs' standing to sue implies that qualified citizens have a right to be considered for jury service. ${ }^{83}$ The states were held to have the right to impose such reasonable qualifications on potential jurors as they wish, but racial considerations were held to be unreasonable. ${ }^{84}$ As to whether jury commissions must be racially representative, the Court stated, "The appellants are no more entitled to proportional representation by race on the jury commission than on any particular grand or petit jury." 85

Finally in Castaneda $v$. Partida, ${ }^{86}$ the Court recognized that systematic exclusion from grand juries (as evidence by a gross discrepancy in the composition of the community and the composition of jury pools) of an ethnic

79. 406 U.S. at 395 (Brennan, J., dissenting).

80. 380 U.S. 202 (1965).

81. Whitus v. Georgia, 385 U.S. 545 (1967); Jones v. Georgia, 389 U.S. 24 (1967); and Sims v. Georgia, 389 U.S. 404 (1967).

82. 396 U.S. $320(1970)$.

83. Id. at $329-30$.

84. The remedy cited with approval by the Court was the construction of a new jury roll. 396 U.S. at 340 n. 46 .

85. Id. at 339. Timing of a challenge to grand jury composition has been held all important, first in Davis v. United States, 411 U.S. 233 (1973) (challenge to a federal grand jury selection process), and then in Francis v. Henderson, 425 U.S. 536 (1976) (challenge to a state grand jury selection process), both cases holding that a collateral attack is too late.

86. 430 U.S. 482 (1977). 
minority, Mexican-Americans, is unconstitutional. Presumably, such exclusion from petit juries will also be held invalid.

\section{Sex}

A Florida statute which systematically excused women from jury service was upheld in Hoyt $v$. Florida ${ }^{87}$ in 1961 , Stewart and Brennan joined in the majority opinion. But fourteen years later, an identical Louisiana statute was struck down in Taylor $v$. Louisiana, ${ }^{88}$ again Stewart and Brennan joined the majority. Although Taylor was a male, the Court ruled that he had standing to challenge the statute since it was his right to a jury pool consisting of a fair cross section of the community that was threatened by the operation of the statute. ${ }^{89}$

Louisiana argued that many women would face special hardship if called for jury duty, and that the state would be faced with the administrative burden of sorting out those who could serve. The statute thus shifted the burden to women; they were required to file a letter with the clerk of court requesting that their names be added to the jury list if they wished to serve. Justice White stated:

It is untenable to suggest these days that it would be a special hardship for each and every woman to perform jury service or that society cannot spare any women from their present duties. This may be the case with many, and it may be burdensome to sort out those who should be exempted from those who should serve. But the task is performed in the case of men, and the administrative convenience in dealing with women as a class is insufficient justification for diluting the quality of community judgment represented by the jury in criminal trials. ${ }^{90}$

.. [A] flavor, a distinct quality is lost if either sex is excluded. The exclusion of one [sex] may indeed make the jury less representative of the community than would be true if an economic or racial group were excluded..$^{91}$

One week later, however, the Court limited the Taylor rule by declaring that it was not to be applied retroactively to decisions obtained by juries impaneled prior to the Taylor decision. The per curiam opinion in Daniel $v$. Louisiana ${ }^{92}$ cited DeStefano ${ }^{93}$ as controlling. Only Justice Douglas protested the inequity of the Court's accepting one of many cases raising this issue and giving relief only to the individual appellant by a prospective rather than a retroactive decision. ${ }^{94}$ The same day Taylor was limited, the Court decided Test $v$.

\footnotetext{
87. 368 U.S. 57 (1961).

88. 419 U.S. 522 (1975).

89. Id. at 526. The right was inferred from the Carter decision, 396 U.S. 320,330 (1970), and from Williams v. Florida, 399 U.S. 78, 100 (1970).

90. 419 U.S. at 534-35.

91. Id. at 532 (quoting from Ballard v. United States, 329 U.S. 187, 193.94 (1946)).

92. 420 U.S. 31 (1975).

93. 392 U.S. 631 (1968). See text and notes at 16, supra.

94. 420 U.S. at 33-34. (Douglas, J., dissenting).
} 
United States ${ }^{95}$ in which a federal statute, the Jury Selection and Service Act of $1968,{ }^{\mathbf{9}}$ was interpreted to give a litigant an unqualified right to inspect jury lists for signs of any defects in the selection process and to use the lists in preparing challenges to the jury selection procedure.

\section{Capital-punishment Qualified}

The issue whether a defendant who is tried on a capital charge has a right to a jury pool from which those opposed to the death penalty have not been systematically excluded was raised in 1968 in Witherspoon v. Illinois. ${ }^{97}$ An Illinois statute allowed the prosecution in a capital case to challenge for cause any juror who "state[s] that he has conscientious scruples against capital punishment, or that he is opposed to the same." 98 In Witherspoon, the prosecution had successfully challenged over half of the veniremen because of their general objections to the death penalty. Only five of the forty-seven challenged stated that under no circumstances could they agree to recommend the death sentence. ${ }^{99}$

Justice Stewart, noting that a growing proportion of the American public no longer supports the imposition of capital punishment, discussed the effect of the exclusion of that group from juries in capital cases:

A man who opposes the death penalty, no less than one who favors it, can make the discretionary judgment entrusted to him by the State and can thus obey the oath he takes as a juror. But a jury from which all such men have been excluded cannot perform the task demanded of it ... [A] jury that must choose between life imprisonment and capital punishment can do little more-and must do nothing less - than express the conscience of the community on the ultimate question of life or death. Yet, in a nation less than half of whose people believe in the death penalty, a jury composed exclusively of such people cannot speak for the community. Culled of all who harbor doubts about the wisdom of capital punishment - of all who would be reluctant to pronounce the extreme penalty-such a jury can speak only for a distinct and dwindling minority. ${ }^{100}$

In the years following Witherspoon, the Burger Court refused to limit it to prospective application and remanded several cases in light of Witherspoon. ${ }^{101}$

The strongest affirmation of the Witherspoon standard came in 1976 in Davis $\%$. Georgia, ${ }^{102}$ a case in which only one "death-scrupled juror" ${ }^{103}$ was ex-

95. 420 U.S. $28(1975)$.

96. 28 U.S.C. $\S \S 1861-74$ et seq. (1976).

97. 391 U.S. 510 (1968).

98. Id. at 512 .

99. Id. at 514 .

100. Id. at $519-20$.

101. In Boulden v. Holman, 394 U.S. 478 (1969), Stewart quoted Witherspoon, saying, "The most that can be demanded of a venireman ... is that he be willing to consider all the penalties provided by state law." id. at 482, and in Maxwell v. Bishop. 398 U.S. 262 (1970), a 1962 rape conviction was remanded because the jury selection process violated Witherspoon.

102. 429 U.S. 122 (1976).

103. Id. at 122 . 
cluded wrongly from the panel. There was nothing on the record to indicate systematic exclusion of conscientious objectors. Nevertheless, the conviction was reversed and remanded, the Court saying, "if a veniremen is improperly excluded even though not [committed to vote against the death penalty before the trial has begun], any subsequently imposed death penalty cannot stand." 104

The limits of Witherspoon were defined in 1978 by the decision in Lockett $v$. Ohio. ${ }^{105}$ There it was decided that the exclusion of prospective jurors who made it "unmistakably clear" that they could not hear the case impartially because of their objections to the death penalty was proper. "Nothing in Taylor . . suggests that the right to a representative jury includes the right to be tried by jurors who have explicitly indicated an inability to follow the law and instructions of the trial judge." ${ }^{106}$

A representative jury, then, may be composed completely of one race or gender, so long as other races and genders are not systematically excluded, but the state bears the burden of explaining the disproportionate composition of the pool. A jury in a capital case must not exclude those who voice general objections to the death penalty, but may properly exclude those who indicate that their verdict will be influenced by the possible death sentence to such an extent that they could not hear the case impartially.

\section{Bias}

\section{Pretrial Publicity}

The Warren Court found pretrial publicity to be so prejudicial in a number of cases as to cause convictions to be invalidated. ${ }^{107}$ The most notable of these cases were Estes $v$. Texas ${ }^{108}$ and Sheppard v. Maxwell. ${ }^{109}$ In Estes, television coverage of the trial, in and of itself, was held sufficiently unfair to invalidate this conviction" ${ }^{10}$ and "Dr. Sam" Sheppard's trial was called a "Roman holiday." 11 The Sixth Amendment rights of defendants were held to dominate the First Amendment rights of the media.

The Burger Court qualified the holdings in Estes and Sheppard to some extent in the cases of Murphy $v$. Florida ${ }^{112}$ and Dobbert $v$. Florida. ${ }^{113}$ The emphasis has been shifted from pretrial publicity to the "totality of the circumstances" with the "circus atmosphere" being the culprit rather than the

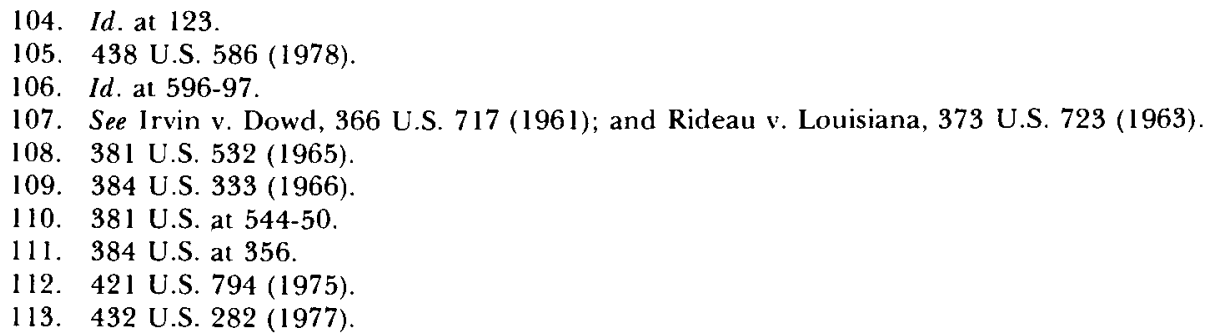


pretrial knowledge of the jury, gleaned from the media publicity. "14 "[Q]ualified jurors need not . . . be totally ignorant of the facts and issues involved." 115 Quoting from Irvin $v$. Dowd, "It is sufficient if the juror can lay aside his impression or opinion and render a verdict based on the evidence presented in court."116 If the judge obtains the juror's assurance that he can be impartial, then "it remains open to the defendant to demonstrate . . . such hostility by the jurors who served in his trail as to suggest a partiality that could not be laid aside."117

The Estes and Sheppard decisions rested not on showings of hostility but merely on the opinion of the Court that impartiality must have been impossible under the prevailing circumstances. The Murphy and Dobbert decisions put a much greater burden on the defendant to demonstrate impartiality in fact due to media coverage or other pretrial factors.

\section{Racial Prejudice}

The defendant in Ham v. South Carolina ${ }^{118}$ was convicted of a drug-related offense in a jury trial. Ham was well-known in his small South Carolina community because of his civil rights activities, and he claimed that the drug charge was a frame by the police who were "out to get him." ${ }^{19}$ During the voir dire, the judge refused to ask any questions directed at identifying possible racial prejudice among members of the jury panel. The Supreme Court reversed Ham's conviction on the grounds that the due process clause of the Fourteenth Amendment guaranteed a defendant the right to select a fair and impartial jury.

The holding was based in part on a 1931 case, Aldridge $v$. United States, ${ }^{120}$ a federal case in which the defendant was a black man being tried for the murder of a white policeman. His conviction was reversed because of the trial judge's failure to interrogate the jury concerning their possible racial prejudice. The Aldridge holding was not based on Constitutional grounds, but rather on the "essential demands of fairness." 121 Justice Rehnquist's opinion in Ham raised the issue to a constitutional level by stating that, "one of the purposes of the Due Process Clause of the Fourteenth Amendment is to insure the 'essential demands of fairness.' "122

The Ham case seemed to enunciate a broad rule constitutionally requiring the asking of questions aimed directly at racial prejudice if that issue was re-

114. See 421 U.S. at $799 ; 432$ U.S. at 302.

115. 421 U.S. at 799-800. For a discussion of the merits of using knowledgeable jurors, see generally, Hassett, A Jury's Pre-trial Knowledge in Historical Perspective: The Distinction Between Pre-trial Information and "Prejudicial" Publicity, 43:4 LAw \& Contemp. Prob. 155 (1980).

116. 421 U.S. at 800 (quoting Irvin v. Dowd, 366 U.S. 717, 723 (1961)).

117. Id.

118. 409 U.S. 524 (1973)

119. Id. at 525 .

120. 283 U.S. 308 (1931)

121. Id. at 310 .

122. 409 U.S. at 526. 
lated to the facts of a case. The holding was narrowed considerably, however, in Ristaino $v$. Ross, ${ }^{123}$ a state case with facts nearly identical to those of Aldridge. The case arose before Ham was decided, and Justice White would have limited $\mathrm{Ham}$ to prospective application, ${ }^{124}$ but the majority went much further and restricted Ham to its facts. Justice Powell, reciting Ham's civil rights activities, concluded that, "Racial issues . . . were inextricably bound up with the conduct of the trial" because the defendant's reputation and his defense (that of being framed by the police) "were likely to intensify any prejudice that indivual members of the jury might harbor." 125 "The mere fact that the victim of the crimes alleged was a white man and the defendants were Negroes" was not enough in the minds of the Court to cause the issue of racial prejudice to rise to a constitutional level. ${ }^{126}$ Just what would be enough, short of the facts of $\mathrm{Ham}$, is an open question.

Justice White's position would have squared with DeStefano $v$. Woods ${ }^{127}$ and Daniel $v$. Louisiana ${ }^{128}$ and would have preserved the Ham rule for all future cases. The rule was easy to follow-it mandated questions regarding racial prejudice whenever there was an element of racial conflict associated with a case, and the rule cost little in judicial efficiency. Instead, the Ristaino majority chose to muddy the waters by announcing the "inextricably bound" test which is difficult for lower courts to apply and which will doubtless call for further interpretation by the Supreme Court. Marshall and Brennan, both of whom dissented in Ham because they felt the Court had not gone far enough in requiring questions about a whole range of possible prejudice, called the decision in Ristaino "an epitaph" for "the promises inherent in Ham and Aldridge."129

\section{III}

\section{Conclusion}

The Burger Court's posture on jury issues has generally been one of retrenchment. Except in the area of jury representativeness, the Court has modified or limited earlier decisions granting greater access to jury trials and it has significantly weakened the functional utility of a jury by its decisions regarding the number of jurors and unanimity.

Only on the representativeness question has the Burger Court made progress by expanding a party's rights to have a case heard by a jury which more closely reflects the composition of his community. An important issue yet to be heard by the Court is the extent to which age should be considered when looking for a representative jury. Whether the Court will be willing to make further progress in this area is a question for the 1980s.

123. 424 U.S. 589 (1976).

124. Id. at 599 (White, J., concurring).

125. 424 U.S. at 597.

126. Id.

127. 392 U.S. 631 (1968)

128. 420 U.S. 31 (1975).

129. 424 U.S. at 599 (Marshall, J., dissenting). 